Research Article Animal Genetics

\title{
Genetic structure of the endangered Irrawaddy dolphin (Orcaella brevirostris) in the Gulf of Thailand
}

\author{
Yufei Dai ${ }^{1,2, *}$ (D), Rachawadee Chantra ${ }^{3, *}$, Kongkiat Kittiwattanawong ${ }^{4, *}$, Liyuan Zhao ${ }^{1,2}$, \\ Watchara Sakornwimon ${ }^{5}$, Reyilamu Aierken ${ }^{1,2}$, Fuxing $\mathrm{Wu}^{1,2}$ and Xianyan Wang ${ }^{1,2}$ (D) \\ ${ }^{1}$ Third Institute of Oceanography, Ministry of Natural Resources, Laboratory of Marine Biology and \\ Ecology, Xiamen, China. \\ ${ }^{2}$ Fujian Provincial Key Laboratory of Marine Ecological Conservation and Restoration, Xiamen, China. \\ ${ }^{3}$ Marine and Coastal Resources Research Center, The Upper Gulf of Thailand, Samut Sakhon, Thailand. \\ ${ }^{4}$ Phuket Marine Biological Research Center, Phuket, Thailand. \\ ${ }^{5}$ Marine and Coastal Resources Research Center, The Central Gulf of Thailand, Chumphon, Thailand.
}

\begin{abstract}
The Irrawaddy dolphin (Orcaella brevirostris) is an endangered, small cetacean species which is widely distributed in rivers, estuaries, and coastal waters throughout the tropical and subtropical Indo-Pacific. Despite the extensive distribution of this species, little is known of individual movements or genetic exchange among regions in Thailand. Here, we evaluate the genetic diversity and genetic structure of $O$. brevirostris in the eastern, northern and western Gulf of Thailand, and Andaman Sea. Although phylogenetic relationships and network analysis based on 15 haplotypes obtained from 32 individuals reveal no obvious divergence, significant genetic differentiation in mitochondrial DNA (overall $F_{S T}=0.226, P<0.001 ; \Phi_{S T}=0.252, P<0.001$ ) is apparent among regions. Of 18 tested microsatellite loci, 10 are polymorphic and successfully characterized in 28 individuals, revealing significant genetic differentiation (overall $\mathrm{F}_{\mathrm{ST}}=0.077, \mathrm{P}<0.05$ ) among the four sampling sites. Structure analysis reveals two inferred genetic clusters. Additionally, Mantel analysis demonstrates individual-by-individual genetic distances and geographic distances follow an isolation-by-distance model. We speculate that the significant genetic structure of O. brevirostris in Thailand is associated with a combination of geographical distribution patterns, environmental and anthropogenic factors, and local adaptations.
\end{abstract}

Keywords: Mitochondrial DNA, microsatellite, cross-amplification, genetic differentiation, cetacean.

Received: October 08, 2020; Accepted: February 28, 2021.

\section{Introduction}

The Irrawaddy dolphin (Orcaella brevirostris) is a small cetacean species which is widely distributed in rivers, estuaries, and coastal waters throughout the tropical and subtropical Indo-Pacific (Stacey and Arnold, 1999; Minton et al., 2013). Estuarine and coastal populations of this species occur from the northwestern Bay of Bengal, east through the Gulf of Thailand to the Philippines, and south to the Indonesian Archipelago (Stacey and Arnold, 1999; Krützen et al., 2018). Riverine subpopulations occur in three large rivers including Ayeyarwady in Myanmar, Mahakam in Indonesia, and Mekong in Cambodia and southern Lao People's Democratic Republic (Smith and Hobbs, 2002; Kreb, 2004; Beasley et al., 2013). Other subpopulations occur in lagoons and marine appended lakes, such as Chilika in India, Songkhla in Thailand, and Malampaya Sound in the Philippines (Beasley et al., 2002; Dolar et al., 2002; Sutaria and Marsh, 2011).

Different habitat preferences are observed between the $O$. brevirostris populations in fresh waters and coastal waters.

Send correspondence to Xianyan Wang, Third Institute of Oceanography, Ministry of Natural Resources, Laboratory of Marine Biology and Ecology, Xiamen 361005, China. E-mail:wangxianyan @ tio.org.cn.

*These authors contributed equally to this work
In rivers, $O$. brevirostris occur in deeper waters $(10-50 \mathrm{~m})$ at the confluences of two rivers, or above and below rapids, while in estuaries and coastal waters they frequent shallower depths (generally $<10 \mathrm{~m}$ ) within a few kilometers of shore (Dolar et al., 2002; Smith and Hobbs, 2002; Smith et al., 2006; Minton et al., 2011; 2013; Jackson-Ricketts et al., 2018). Because of their patchy and fragmented distribution in rivers and coastal waters, Irrawaddy dolphins are particularly vulnerable to disturbance (Minton et al., 2017). This species is currently classified as Endangered by the International Union for Conservation of Nature (IUCN) in their Red List, and is listed in Appendix I of the Convention on International Trade in Endangered Species of Wild Flora and Fauna (CITES). Because of their small population sizes and declining number, and increasing anthropogenic threats, the three riverine subpopulations (Ayeyarwady, Mahakam, Mekong) and two lacustrine subpopulations (Songkhla, Malampaya) are classified as Critically Endangered by the IUCN (Minton et al., 2017).

In Thailand's waters, $O$. brevirostris occur along the Andaman Sea coast, Songkhla Lake, and many locations along the coast surrounding the Gulf of Thailand (Chantrapornsyl et al., 1996; 1999; Anderson and Kinze, 1999; Beasley et al., 2002; Smith et al., 2003; Kittiwattanawong et al., 2007; Hines et al., 2015). Recently, field observations and acoustic 
studies targeting $O$. brevirostris were conducted at locations such as Trat Bay, Bangpakong Estuary, and Donsak, in the eastern, northern, and western Gulf of Thailand, respectively (Tongnunui et al., 2011; Hines et al., 2015; Jutapruet et al., 2017; Niu et al., 2019; Jackson-Ricketts et al., 2020). Additionally, significantly different isotope values in $O$. brevirostris teeth, indicating strong geographic variation and potential subpopulation structure in the Gulf of Thailand and Andaman Sea coast, have been reported (Jackson-Ricketts et al., 2018). Despite this, little is known about individual movements and genetic exchange of $O$. brevirostris among regions in Thailand.

Understanding genetic diversity and the genetic structure of populations is important to conserve and manage species, especially for inshore dolphins whose isolated populations are highly affected by human activities (Mace and Lande, 1991; Jefferson et al., 2009; Brown et al., 2014). Mitochondrial DNA (mtDNA) has been used as a genetic marker for reconstructing patterns of population demography, admixture, biogeography and speciation, because of its high mutation rate, maternal inheritance and lack of recombination, and high intracellular copy number (Wilson et al., 1985; Hurst and Jiggins, 2005). Recently, there are a few mtDNA-based studies on the genetic diversity and population structure of $O$. brevirostris throughout its distribution range. The mtDNA evidence shows that the Chilika population in India does not share any haplotypes with those of Thailand, Cambodia and Indonesia populations (Jayasankar et al., 2011). Another molecular genetic-related study suggests a long-standing isolation of the Mekong dolphin population from other Orcaella populations, with the remaining population now experiencing low genetic diversity (Krützen et al., 2018). Moreover, significant levels of genetic differentiation are found among three $O$. brevirostris populations, Chilika Lagoon in India, the eastern Gulf of Thailand, and the Mekong River in Cambodia, indicating strong genetic differentiation between coastal and riverine populations and among different geographic locations (Caballero et al., 2019).

Microsatellite markers are short tandem repeats of 1-6 nucleotides that are widespread in the nuclear genomes of most taxa. Due to their high mutation rates, microsatellites are also considered to be robust and informative DNA markers for solving ecological and molecular genetic-related questions, such as those pertaining to bottlenecks, kinship, population structure, and migration (Selkoe and Toonen, 2006; De Barba et al., 2017). There are few known microsatellite sequences for $O$. brevirostris, although several molecular genetic-related studies have been undertaken on this species (Jayasankar et al., 2011; Krützen et al., 2018; Caballero et al., 2019; Kundu et al., 2019). Fortunately, microsatellites with highly conserved flanking regions often allow cross-species amplification from congeneric or confamilial taxa, especially for vertebrates, including mammals (Selkoe and Toonen, 2006; Barbara et al., 2007).

Our research aims were to: (1) assess transferability and polymorphism of microsatellite markers for O brevirostris from closely related dolphin species; (2) evaluate genetic diversity of $O$. brevirostris using samples obtained from throughout the Gulf of Thailand and Andaman Sea coast using mitochondrial control region sequences and nuclear microsatellite markers; and (3) estimate levels of genetic differentiation among these $O$. brevirostris individuals in Thailand for both marker types.

\section{Material and Methods}

\section{Sampling}

All fieldwork was under permits from the Ministry of Agriculture and Rural Affairs of China, and with approval from the Department of Marine and Coastal Resources of Thailand. The relevant CITES Permits (No. 2018CN/IC000475/CH) were obtained for import of samples. There was no issue on ethics in this study.

\section{Sample collection and DNA extraction}

From 2010 to 2018 , muscle or skin samples were collected from 37 dead (stranded) O. brevirostris individuals recovered from nine sites in Thailand: Chachengsao $(n=1)$, Chonburi $(\mathrm{n}=1)$, Chumporn $(\mathrm{n}=2)$, Mueang Trat $(\mathrm{n}=11)$, Phetchaburi $(n=1)$, Samut Sakorn $(n=9)$, Satun $(n=1)$, Surattani $(n=7)$, and Trang $(n=4)$. Geographic coordinates for all except one individual from Phetchaburi were recorded at the time of collection. Samples were grouped into four general regions as described in Jackson-Ricketts et al. (2018), each region encompassing specific sites: (1) Mueang Trat, representing the eastern Gulf of Thailand (EG, $n=11$ ), (2) Chonburi, Chachengsao, Samut Sakorn, and Phetchaburi, making up the northern Gulf (NG, $n=12)$, (3) Chumporn and Surattani, making up the western Gulf (WG, $n=9)$, and (4) Trang and Satun, representing Andaman Sea sites (AS, $\mathrm{n}=5$ ) (Figure 1). Genomic DNA from minced tissue samples was extracted using DNeasy blood and tissue extraction kits (QIAGEN, Valencia, USA) according to the manufacturer instructions.

\section{Mitochondrial DNA amplification}

A fragment of the mitochondrial control region was amplified using forward primer $\mathrm{Ce}-\mathrm{CRF}$ 5'-GAATTCCCCGGTCTTGTAAACC-3' and reverse primer Ce-CRR 5'-TCTCGAGATTTTCAGTGTCTTGCTTT-3' (Hoelzel et al., 1991). Total PCR volume of $(50 \mu \mathrm{L})$ contained approximately $50 \mathrm{ng}$ of genomic DNA, $1 \times$ Easy Taq Mix (Takara, Dalian, China), $1 \mu \mathrm{L}$ of each forward and reverse primer, and $\mathrm{ddH}_{2} \mathrm{O}$ to make up the final volume. The PCR profile comprised an initial denaturation step at $94{ }^{\circ} \mathrm{C}$ for $3 \mathrm{~min}, 35$ cycles of $94{ }^{\circ} \mathrm{C}$ for $30 \mathrm{~s}$, annealing at $50{ }^{\circ} \mathrm{C}$ for $1 \mathrm{~min}$, extension at $72{ }^{\circ} \mathrm{C}$ for $1 \mathrm{~min}$, and a final extension at $72{ }^{\circ} \mathrm{C}$ for $10 \mathrm{~min}$. All PCR products were sequenced in both directions on an ABI 3730 automated DNA sequencer (Applied Biosystems).

\section{Microsatellites crossamplification}

We selected a total of 18 microsatellite markers (Table S1, data unpublished), initially isolated from the IndoPacific humpback dolphin Sousa chinensis, for this study. These loci were all 'perfect-type' and long tandem repeat motifs (e.g., tetra- or pentanucleotide), and demonstrated high polymorphism in Thailand $S$. chinensis populations (data unpublished). Microsatellites were allocated into 6 multiplex 


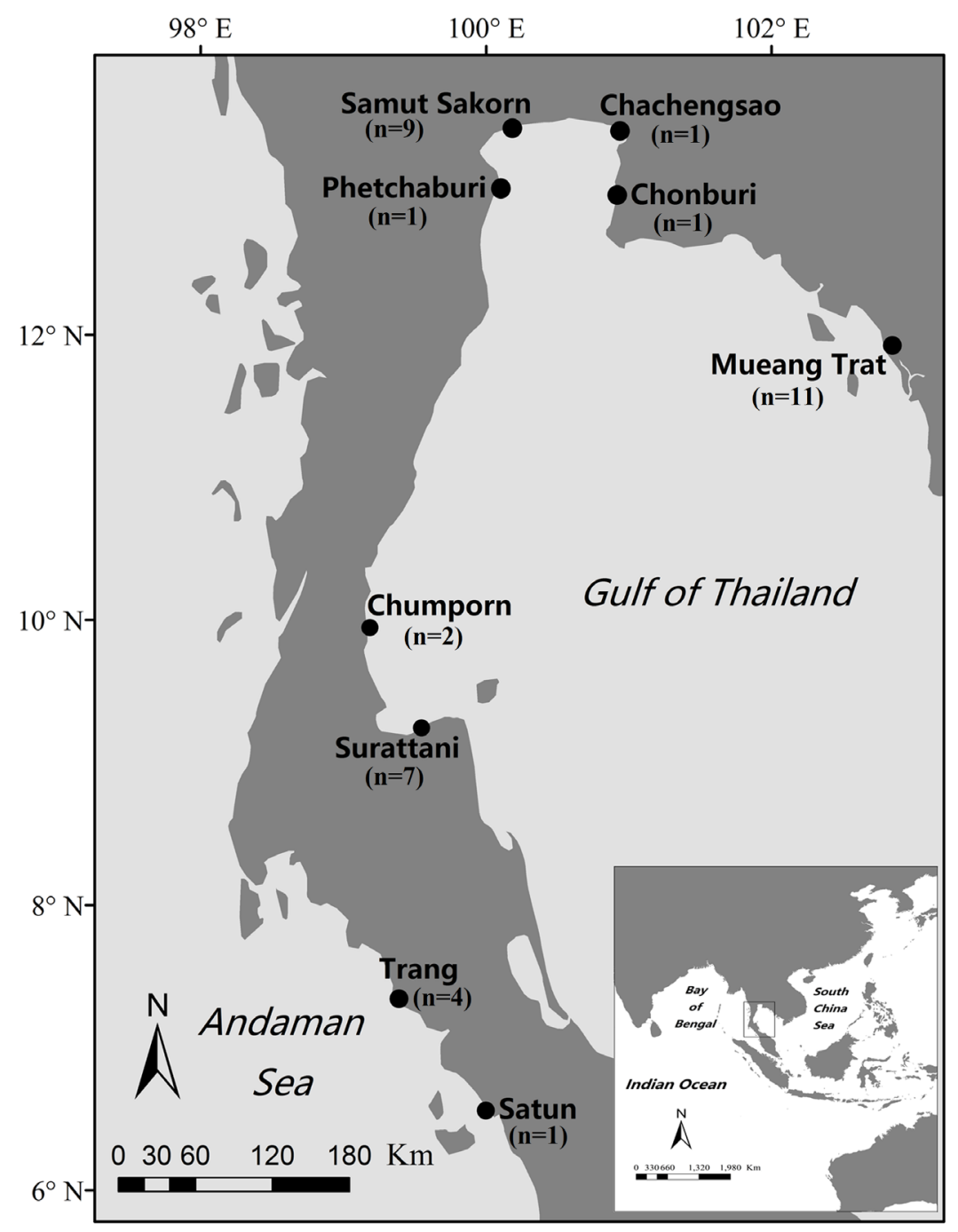

Figure 1 - Locations of sample collection in the Gulf of Thailand and Andaman Sea sites. Mueang Trat represents the eastern Gulf of Thailand (EG); Chonburi, Chachengsao, Samut Sakorn, and Phetchaburi make up the northern Gulf (NG); Chumporn and Surattani make up the western Gulf (WG); Trang and Satun represent the Andaman Sea site (AS).

PCR panels using software MPprimer (Shen et al., 2010), based on annealing temperature, complementarity of primer pairs, and allele size range. The 5' end of each forward primer was labeled with a fluorescent dye (6-FAM, VIC or NED). The total PCR volume $(20 \mu \mathrm{L})$ consisted of approximately 50 ng of genomic DNA, $1 \times$ Multiplex PCR Kit (Takara, Dalian, China), the optimal dosage (Table S1) of each forward and reverse primer, and $\mathrm{ddH}_{2} \mathrm{O}$ added to make up the final volume. PCR conditions involved an initial denaturation step at 94 ${ }^{\circ} \mathrm{C}$ for $3 \mathrm{~min}$, followed by 32 cycles of $94^{\circ} \mathrm{C}$ for $30 \mathrm{~s}$, the specific annealing temperature (Table S1) for $90 \mathrm{~s}$, extension at $72{ }^{\circ} \mathrm{C}$ for $60 \mathrm{~s}$, and a final extension for $30 \mathrm{~min}$ at $60{ }^{\circ} \mathrm{C}$. PCR products were run on an ABI $3730 \mathrm{XL}$ automated DNA sequencer (Applied Biosystems) using GeneScan LIZ 500 as the internal size standard. Allele sizes were automatically scored with GeneMapper version 4.1 (Applied Biosystems) and manually checked.

\section{Detecting genotyping errors}

Genomic DNA obtained from dead individuals may be low in quantity and/or quality, be at increased risk of contamination, and more susceptible to genotyping errors such as allele dropouts and false alleles (Taberlet et al., 1996; Bonin et al., 2004; Pompanon et al., 2005). Therefore, in each multiple PCR batch we used one individual as a positive control for genotyping each locus separately to ensure consistent amplification of alleles. A negative control with no DNA template was also used in each PCR batch to detect possible of contamination during PCR amplification. Moreover, we randomly retested genotypes from four individuals (>10\%) to estimate genotyping error rates for across all 18 loci.

\section{Statistical analyses}

\section{Mitochondrial DNA data analysis}

Raw mtDNA sequences were aligned using the Clustal-W algorithm implemented in the program MEGA version 5.0 (Tamura et al., 2011), then manually checked and edited. MEGA was also used to calculate nucleotide composition, and variable and conserved sites. Diversity measures including numbers of haplotypes $(\mathrm{H})$, specific haplotypes $(\mathrm{SH})$, and nucleotide $(\mathrm{Hd})$ and haplotype diversities $(\pi)$ for each 
region, were analyzed using DnaSP version 5 (Librado and Rozas, 2009). Phylogenetic relationships among haplotypes were constructed using the neighbor-joining (NJ) method implemented with 1000 bootstrap replicates in MEGA. A haplotype network was constructed using the software PopART (Leigh and Bryant, 2015). We also used Arlequin version 3.0 (Excoffier et al., 2005) to investigate genetic variation among regions by calculating both $\mathrm{F}_{\mathrm{ST}}$ and $\Phi_{\mathrm{ST}}$ values with 1000 random permutations.

\section{Microsatellite data analysis}

GenAIEx version 6.501 (Peakall and Smouse 2006, 2012) was used to estimate the number of alleles per locus $(\mathrm{Na})$, effective number of alleles $(\mathrm{Ne})$, observed heterozygosity (Ho), expected heterozygosity (He), unbiased expected heterozygosity (uHe), Shannon's information index (I), and Fixation Index (F). Genepop version 4.0.7 (Rousset, 2008) was used to test departure from Hardy-Weinberg equilibrium (HWE) and linkage disequilibrium (LD) among all pairs of loci. Myriads version 1.1 (Carvajal-Rodriguez, 2018) was performed to correct the p-value-based multiple testing by Bonferroni sequential correction procedures. To check for signs of genetic bottlenecks, which cause an heterozygosity excess in populations, BOTTLENECK version 1.2.02 (Cornuet and Luikart, 1996; Piry et al., 1999) was used under the infinite allele model (IAM), stepwise mutation model (SMM), and two-phased model (TPM), based on 1000 iterations. We used the Wilcoxon sign-rank test to estimate significance because only 10 microsatellite loci were included in analysis (Wilcoxon, 1945). Micro-Checker version 2.2.3 (Van Oosterhout et al., 2004) was used to detect occurrences of null alleles, allele dropout, or scoring error for each locus, with $95 \%$ confidence intervals.

Genetic structure and number of genetic clusters $(\mathrm{K})$ were determined using Structure 2.3.4 (Pritchard et al., 2000) based on genotyping data generated from the 6 multiplex PCR panels in this study. For all analyses, the length of the burn-in period was set to $10^{5}$ iterations, followed by $10^{6}$ in the number of MCMC repetitions. Then, the Admixture model was used with correlated allele frequencies. The Locprior model was chosen to infer possible weak population structure with the assistance of sample group information (Hubisz et al., 2009). The number of inferred $\mathrm{K}$ was set between 1 and 6 , and 20 independent replicates were run for each $\mathrm{K}$ value. Subsequently, the web program Structure Harvester version 0.6.94 (Earl and VonHoldt, 2012) was used to calculate the Delta $\mathrm{K}$ value and determine the best number of $\mathrm{K}$ clusters (Evanno et al., 2005). We used CLUMPP version 1.1.2 (Jakobsson and Rosenberg, 2007) to summarize the optimal alignment of the 20 replicates for the same K value. Final results were displayed graphically with Distruct version 1.1 (Rosenberg, 2004).

FSTAT version 2.9.3.2 (Goudet, 1995, update in Feb. 2002) was used to estimate genetic differentiation $F_{S T}$ (Weir and Cockerham, 1984) among the four geographic regions based on 1000 permutations. A principal coordinate analysis (PCoA) was performed in GenAIEx based on the standardized covariance of the individual-by-individual genetic distance matrix (Peakall et al., 1995; Smouse and Peakall, 1999). In addition, Mantel analysis (Mantel, 1967) was used in GenAIEx to test isolation by distance (IBD) by performing the correlation between matrices of individual-by-individual genetic distances and geographic distances measured as the distance between two individuals calculated from sampling location coordinates. We conducted a second IBD analysis excluding the genetic and geographical data for AS samples because of the large distance between AS and other regions. Both tests were run with 999 random permutations in GenAIEx.

\section{Data availability}

The 18 tested microsatellite sequences and 32 obtained mtDNA control region sequences (including $15 \mathrm{mtDNA}$ haplotypes) reported in this paper have been deposited into the GenBank database under the accession numbers of MK766845-MK766870 (Table S1) and MT738330MT738361 (Table S2), respectively.

\section{Results}

\section{Available genetic data for analysis}

No contamination was detected during PCRs, and no genotyping errors were observed when randomly retesting four individuals. Among the 18 loci tested, two (Sch5878 and Sch5685) were excluded because of unsuccessful amplification, and six (Sch7427, Sch193, Sch4657, Sch5373, Sch974, Sch5094) were excluded because they were monomorphic. The remaining 10 loci were polymorphic in the four sampling locations.

Due to the low quality of some DNA samples, we obtained mtDNA sequences for 32 individuals (Table S2) only, including two from AS, eight from WG, 10 from EG, and 12 from NG. For microsatellite data analysis, only DNA samples for which at least eight of the 10 polymorphic loci were successfully genotyped were included. Therefore, nine samples (two from EG, three from AS, and four from WG) were removed because of poor amplification success. Finally, we generated genotypes of 10 microsatellites for 28 individuals only, including two individuals from AS, five from $\mathrm{WG}$, nine from EG, and 12 from NG. Allele frequency distributions in the four geographic regions based on 10 polymorphic loci are graphically represented in Figure 2.

\section{Genetic diversity}

Based on mtDNA data, 15 haplotypes were found in the 32 individuals by a consensus 883 bp sequences from the four geographic locations (Figure 3). Only one haplotype was shared between NG and WG. Genetic diversity estimates of $\mathrm{H}, \mathrm{SH}, \mathrm{Hd}$, and $\pi$ values for each region are summarized in Table 1. NG showed the most haplotypes $(n=6)$, while AS exhibited the least $(n=2)$. Estimated Hd was high (mean value $=0.925 \pm 0.025$ ), but observed $\pi$ was relatively low (mean $0.009 \pm 0.001)$. Although AS exhibited the highest Hd and $\pi$ values among the four geographic regions, only 2 individuals were included in genetic analysis.

Based on microsatellite DNA data, genetic diversity estimates of $\mathrm{Na}, \mathrm{Ne}, \mathrm{Ho}, \mathrm{He}$, uHe, I and $\mathrm{F}$ values for each sampling site are summarized in Table 2. Average $\mathrm{Na}$ and $\mathrm{Ne}$ were highest in NG, with values of $4.000 \pm 0.683$ and 2.581 \pm 0.519 , respectively. The highest mean He and I were in EG, 

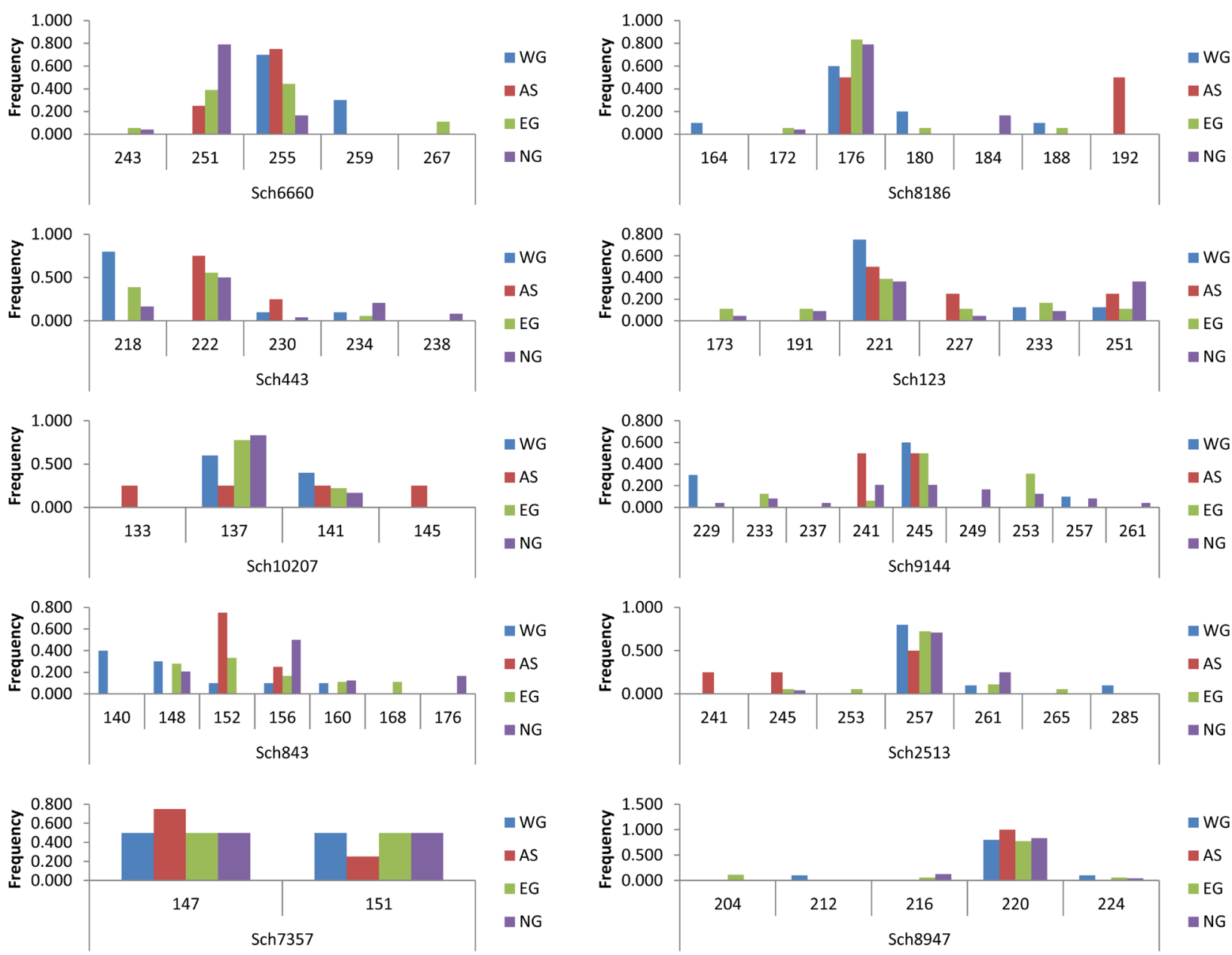

Figure 2 - Allele frequencies with graphs by each sampling location and each locus for microsatellite data. Allele frequencies are displayed for 10 polymorphic microsatellites, and different colors represent different regions in Thailand.

\begin{tabular}{|c|c|c|c|c|c|}
\hline \multirow[b]{2}{*}{ Haplotype } & Variable sites $(883 \mathrm{bp})$ & \multicolumn{4}{|c|}{ Geographic location } \\
\hline & $\begin{array}{llllllllllllllllllllllllllll} & & & & & 1 & 1 & 1 & 2 & 2 & 2 & 3 & 3 & 3 & 3 & 3 & 3 & 3 & 3 & 4 & 5 & 5 & 5 & 5 & 5 & 6 & 6 & 7 \\
1 & 2 & 4 & 4 & 8 & 1 & 6 & 9 & 0 & 6 & 8 & 0 & 0 & 2 & 5 & 6 & 9 & 9 & 9 & 5 & 0 & 0 & 0 & 2 & 3 & 0 & 9 & 6 \\
8 & 7 & 4 & 5 & 7 & 0 & 7 & 8 & 3 & 8 & 2 & 0 & 2 & 4 & 6 & 9 & 0 & 1 & 2 & 0 & 0 & 1 & 4 & 4 & 7 & 2 & 6 & 6 \\
\end{array}$ & EG & WG & NG & AS \\
\hline Hap 1 & $\mathrm{C}$ C G C T A T T T T C C G A T T C C C C G T A C G A C T & - & 3 & 1 & - \\
\hline Hap 2 & . . . G & - & - & 6 & - \\
\hline Hap 3 & . . C. . & - & - & 1 & - \\
\hline Hap 4 & . & 2 & - & - & - \\
\hline Hap 5 & G. C C. & - & 3 & - & - \\
\hline Hap 6 & $\mathrm{G} . \ldots \mathrm{T}$. & 2 & - & - & - \\
\hline Hap 7 & G $\mathrm{T}$ & - & - & - & 1 \\
\hline Hap 8 & $\mathrm{G} \mathrm{T}$ & - & 1 & - & - \\
\hline Hap 9 & . $\mathrm{GC} \ldots \mathrm{T}$. & - & - & 2 & - \\
\hline Hap 10 & $\ldots \mathrm{GC} \ldots \mathrm{C} \mathrm{T} \ldots$ & - & - & 1 & - \\
\hline Hap 11 & G. & 1 & - & - & - \\
\hline Hap 12 & . T. & - & - & - & 1 \\
\hline Hap 13 & $\mathrm{~T} . \mathrm{T}$. & - & - & 1 & - \\
\hline Hap 14 & $\ldots \mathrm{C} G \ldots \mathrm{C}$ T $\mathrm{T} . \mathrm{G} . \mathrm{C} . \mathrm{T} . \mathrm{T} \mathrm{A} C \ldots$ & 5 & - & - & - \\
\hline Hap 15 & 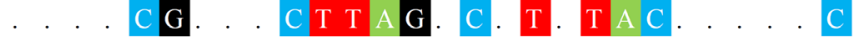 & - & 1 & - & - \\
\hline Total sample size & & 10 & 8 & 12 & 2 \\
\hline
\end{tabular}

Figure 3 - Polymorphic sites of mtDNA haplotypes identified among the four geographic regions in Thailand. Nucleotide position and geographic location are at the top, respectively. 
with values $0.531 \pm 0.053$ and $0.986 \pm 0.117$, respectively (Figure 4). Although AS had the lowest I $(0.710 \pm 0.119)$ and $\mathrm{He}(0.450 \pm 0.065)$, it had the highest $\mathrm{Ho}(0.600 \pm 0.125)$ and $\mathrm{uHe}(0.633 \pm 0.096)$. One locus significantly deviated from HWE $(\mathrm{P}<0.05)$ in each of WG, EG, and NG (Table S3). Except for AS (because the sample size was too small to analyze), the other three locations had no significant bottleneck under any model of mutation (Wilcoxon test: $\mathrm{P}>0.05$ ). No significant LD was found in any pairs of the 10 tested loci after
Bonferroni sequential correction. No evidence of large allele dropout or scoring errors was detected by Micro-Checker.

ANOVA results revealed $\mathrm{Na}$ values differed significantly from each other among sampled regions (ANOVA: $\mathrm{F}_{3,36}$ $=3.279, \mathrm{P}=0.032)$, but $\mathrm{Ne}$ values did not $\left(\mathrm{F}_{3,36}=0.657\right.$, $\mathrm{P}=0.584)$. There were no significant differences among $\mathrm{He}$ $\left(\mathrm{F}_{3,36}=0.442, \mathrm{P}=0.725\right)$ and $\mathrm{uHe}\left(\mathrm{F}_{3,36}=0.559, \mathrm{P}=0.646\right)$ values. Additionally, no significant differences were found among Ho $\left(\mathrm{F}_{3,36}=0.213, \mathrm{P}=0.887\right)$ and $\mathrm{I}\left(\mathrm{F}_{3,36}=1.151\right.$, $\mathrm{P}=0.342$ ) values from any of the four geographic regions.

Table 1 - Information and molecular indices for $O$. brevirostris based on mtDNA control region sequences.

\begin{tabular}{|c|c|c|c|c|c|}
\hline Population & Number & $\mathrm{H}$ & $\mathrm{SH}$ & $\mathrm{Hd} \pm \mathrm{SD}$ & $\pi \pm \mathrm{SD}$ \\
\hline WG & 8 & 4 & 3 & $0.786+/-0.113$ & $0.009+/-0.002$ \\
\hline AS & 2 & 2 & 2 & $1.000+/-0.500$ & $0.014+/-0.007$ \\
\hline EG & 10 & 4 & 4 & $0.733+/-0.120$ & $0.009+/-0.001$ \\
\hline NG & 12 & 6 & 5 & $0.758+/-0.122$ & $0.005+/-0.001$ \\
\hline Total & 32 & 15 & 14 & $0.925+/-0.025$ & $0.009+/-0.001$ \\
\hline
\end{tabular}

Note: $\mathrm{H}$ is the number of haplotypes, $\mathrm{SH}$ is the number of specific haplotypes, $\mathrm{Hd}$ is the haplotype diversity, $\pi$ is the nucleotide diversity.

Table 2 - Genetic diversity parameters of $O$. brevirostris in the four geographic regions in Thailand.

\begin{tabular}{|c|c|c|c|c|c|c|c|c|c|}
\hline Sampling region & & $\mathrm{N}$ & $\mathrm{Na}$ & $\mathrm{Ne}$ & I & Ho & $\mathrm{He}$ & $\mathrm{uHe}$ & $\mathrm{F}$ \\
\hline WG & Mean & 4.900 & 3.000 & 2.000 & 0.804 & 0.530 & 0.467 & 0.520 & -0.102 \\
\hline$(\mathrm{n}=5)$ & S.E. & 0.100 & 0.298 & 0.198 & 0.083 & 0.084 & 0.039 & 0.043 & 0.120 \\
\hline AS & Mean & 1.900 & 2.300 & 2.073 & 0.710 & 0.600 & 0.450 & 0.633 & -0.319 \\
\hline$(n=2)$ & S.E. & 0.100 & 0.260 & 0.268 & 0.119 & 0.125 & 0.065 & 0.096 & 0.172 \\
\hline EG & Mean & 8.900 & 3.900 & 2.456 & 0.986 & 0.507 & 0.531 & 0.563 & 0.064 \\
\hline$(n=9)$ & S.E. & 0.100 & 0.407 & 0.334 & 0.117 & 0.066 & 0.053 & 0.056 & 0.070 \\
\hline NG & Mean & 11.900 & 4.000 & 2.581 & 0.966 & 0.522 & 0.509 & 0.531 & -0.026 \\
\hline$(\mathrm{n}=12)$ & S.E. & 0.100 & 0.683 & 0.519 & 0.162 & 0.071 & 0.064 & 0.067 & 0.050 \\
\hline
\end{tabular}

Note: $\mathrm{N}$ is the number of sample size, $\mathrm{Na}$ is the number of alleles, Ne is the number of effective alleles, I is the Shannon's information index, Ho is the observed heterozygosity, He is the expected heterozygosity, uHe is the unbiased expected heterozygosity, F is the fixation index, S.E. is the standard error.

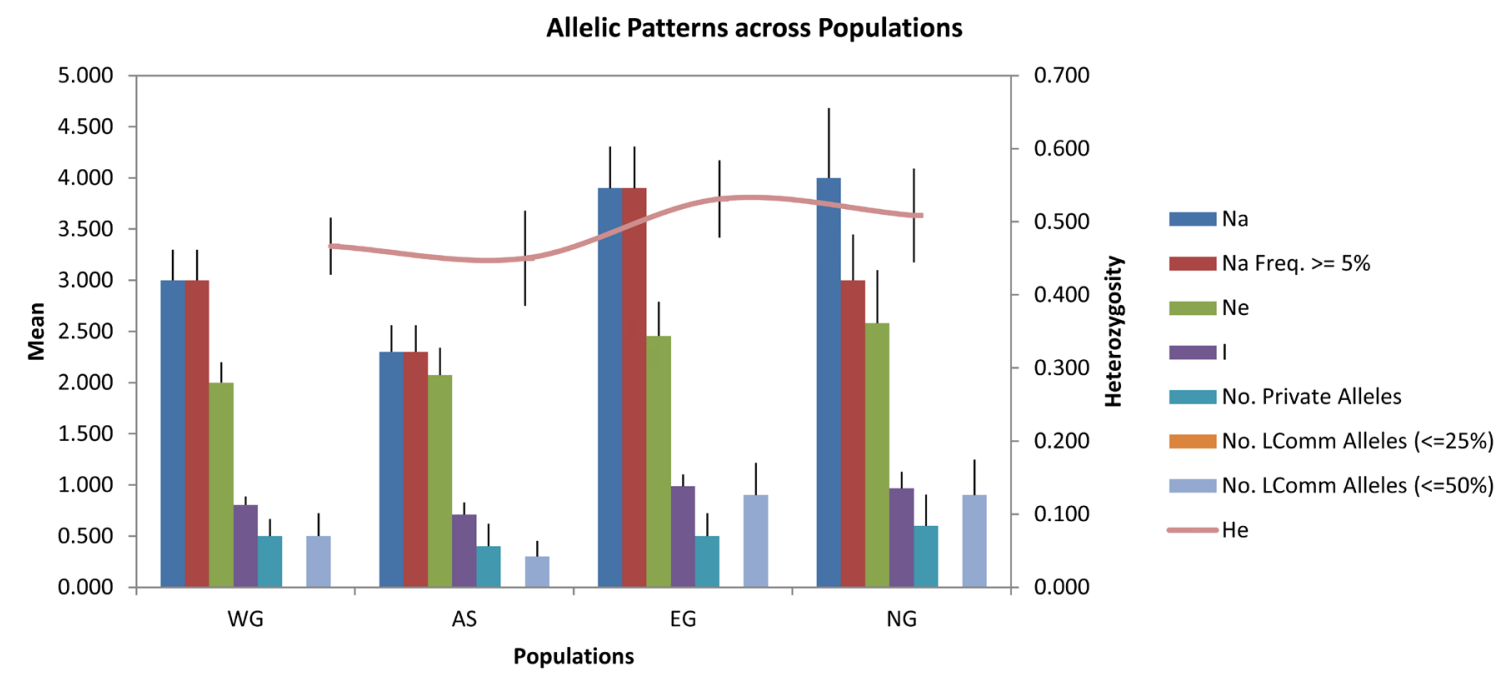

Figure 4 - Allelic patterns across regions in the geographic distribution of $O$. brevirostris in Thailand. Na is the number of different alleles, Na Freq. is the number of common alleles with a frequency $\geq 5 \%$, Ne is the effective number of alleles, I is the Shannon's information index, No. LComm Alleles are the number of locally common alleles (Freq. $>=5 \%$ ) found in $50 \%$ or $25 \%$ or fewer populations, and He represented by the curve is the expected heterozygosity. 


\section{Genetic differentiation}

The NJ tree was constructed based on the 15 haplotypes of $O$. brevirostris and the two outgroup mtDNA sequences from Orcinus orca and Steno bredanensis. Haplotypes from different regions were randomly distributed on the NJ tree, with no phylogenetic structure corresponding to geography apparent (Figure 5A). The network also showed similar results with the NJ tree, without obvious divergence of haplotypes from different sites. Levels of divergence among most haplotypes were low. However, divergence from Hap_14 in EG and Hap_15 in WG to other haplotypes was extremely high. Both Hap_7 and Hap_12 (defined by two AS individuals) were also highly divergent from other haplotypes (Figure 5B).

AMOVA results revealed significant high genetic differentiation in mtDNA (overall $\mathrm{F}_{\mathrm{ST}}=0.226, \mathrm{P}<0.001 ; \Phi_{\mathrm{ST}}=$ $0.252, \mathrm{P}<0.001$ ) among Thailand $O$. brevirostris individuals. Pairwise $\mathrm{F}_{\mathrm{ST}}$ and $\Phi_{\mathrm{ST}}$ values revealed moderate to high levels of genetic differentiation between different region pairs, but some cases showed no significant differentiation between AS and other region pairs (Table 3). For microsatellites, the estimated $\mathrm{F}_{\mathrm{ST}}$ value revealed low but significant genetic differentiation (overall $\mathrm{F}_{\mathrm{ST}}=0.077, \mathrm{P}<0.05$ ) among the four geographic regions. Low to moderate levels of genetic differentiation were detected between different region pairs. Estimates of pairwise $\mathrm{F}_{\mathrm{ST}}$ are presented in Table 4. Pairwise differentiations were all significant $(\mathrm{P}<0.05)$, except for the pair of EG and AS, which had the lowest genetic differentiation (pairwise $\mathrm{F}_{\mathrm{ST}}=0.008, \mathrm{P}>0.05$ ). Some pairwise $\mathrm{F}_{\mathrm{ST}}$ values were moderately differentiated, with the highest genetic differentiation found between $\mathrm{WG}$ and $\mathrm{NG}$ (pairwise $\mathrm{F}_{\mathrm{ST}}=$ $0.166, \mathrm{P}<0.01$ ). AMOVA results for the degree of variance in O. brevirostris individuals are summarized in Table 5. There was $7.706 \%$ genetic variance among the four geographic regions, $6.676 \%$ variance among individuals within region, and $85.618 \%$ variance within individuals.

A

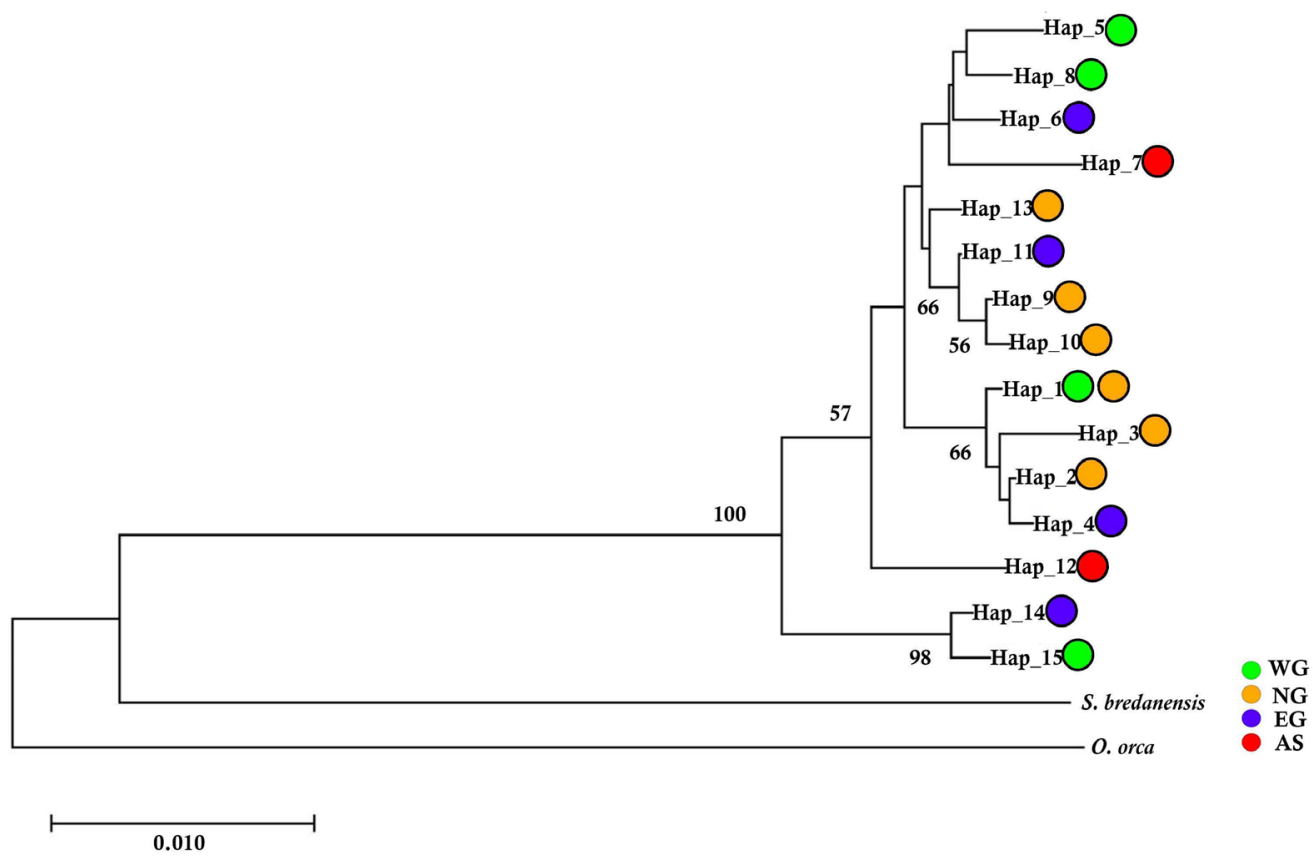

B

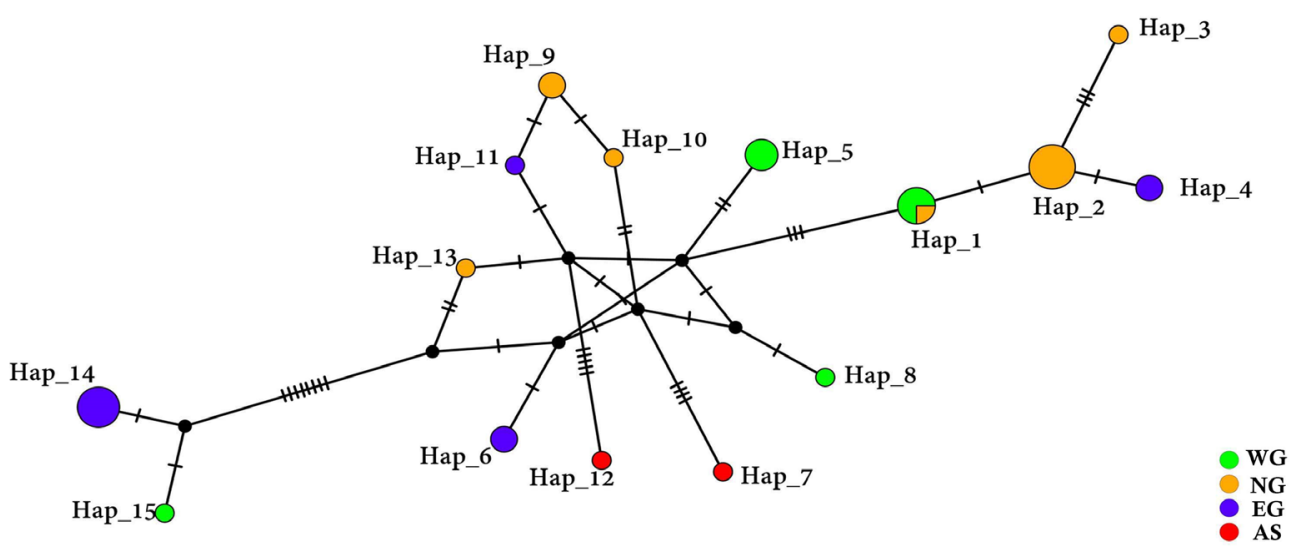

Figure 5 - Genetic structures of all 15 mtDNA haplotypes of $O$. brevirostris in Thailand. (A) Neighbour-joining tree of mtDNA haplotypes. Orcinus orca and Steno bredanensis are used as the outgroup species. Only bootstraps values $>50 \%$ are shown. (B) Network of mtDNA haplotypes. Size of the circles represents the frequency of haplotype, and dash lines represent the number of mutational steps between haplotypes. Colors indicate the sampling location(s) for each haplotype. 
PCoA plots of individuals based on the standardized covariance of genetic distance matrix revealed that the large genetic distance was detected between individuals from WG and $\mathrm{NG}$, indicating the high level of genetic differentiation.
Axis coordinates 1 and 2 accounted for $17.901 \%$ and $12.988 \%$ of the total variance, respectively (Figure 6).

Structure Harvester analysis revealed there were most likely only two clusters (Delta $\mathrm{K}=2.0$, Figure 7 ). The modal

Table 3 - Matrix of pairwise $\Phi_{\mathrm{ST}}$ (above diagonal) and $\mathrm{F}_{\mathrm{ST}}$ (below diagonal) values among the four geographic regions based on mtDNA control region sequences.

\begin{tabular}{ccccc}
\hline$\Phi_{\mathrm{ST}}$ & $\mathrm{WG}$ & $\mathrm{AS}$ & $\mathrm{EG}$ & $\mathrm{NG}$ \\
\hline $\mathrm{WG}$ & - & 0.118 & $0.197 *$ & $0.160^{*}$ \\
$\mathrm{AS}$ & 0.158 & - & $0.291^{*}$ & $0.363^{*}$ \\
$\mathrm{EG}$ & $0.242^{* *}$ & 0.202 & - & $0.348^{* *}$ \\
$\mathrm{NG}$ & $0.205^{* *}$ & 0.184 & $0.254^{* *}$ \\
\hline
\end{tabular}

Note: $* \mathrm{P}<0.05, * * \mathrm{P}<0.01$.

Table 4 - Pairwise $\mathrm{F}_{\mathrm{ST}}$ estimates among the four geographic regions based on microsatellites.

\begin{tabular}{|c|c|c|c|c|}
\hline Population & WG & AS & EG & $\mathrm{NG}$ \\
\hline WG & - & & & \\
\hline AS & $0.121^{*}$ & - & & \\
\hline EG & $0.060^{*}$ & 0.008 & - & \\
\hline NG & $0.166^{* *}$ & $0.101 *$ & $0.034 *$ & - \\
\hline
\end{tabular}

Note: $* \mathrm{P}<0.05, * * \mathrm{P}<0.01$.

Table 5 - Analysis of molecular variance of $O$. brevirostris in the four sampled regions.

\begin{tabular}{lcccc}
\hline Source of variation & df & SS & MS & Est. Var. \\
\hline Among populations & 3 & 17.679 & 5.893 & 0.231 \\
$\begin{array}{l}\text { Among individuals } \\
\text { with population }\end{array}$ & 24 & 71.339 & 2.972 & 0.201 \\
Within individuals & 28 & 72.000 & 2.571 & 2.571 \\
Total & 55 & 161.018 & & 3.003 \\
\hline
\end{tabular}

Note: $\mathrm{df}$ is the degrees of freedom, SS is the sums of squares, MS is the mean squares, Est. Var. is the estimated variance within and among populations.

Principal Coordinates (PCoA)

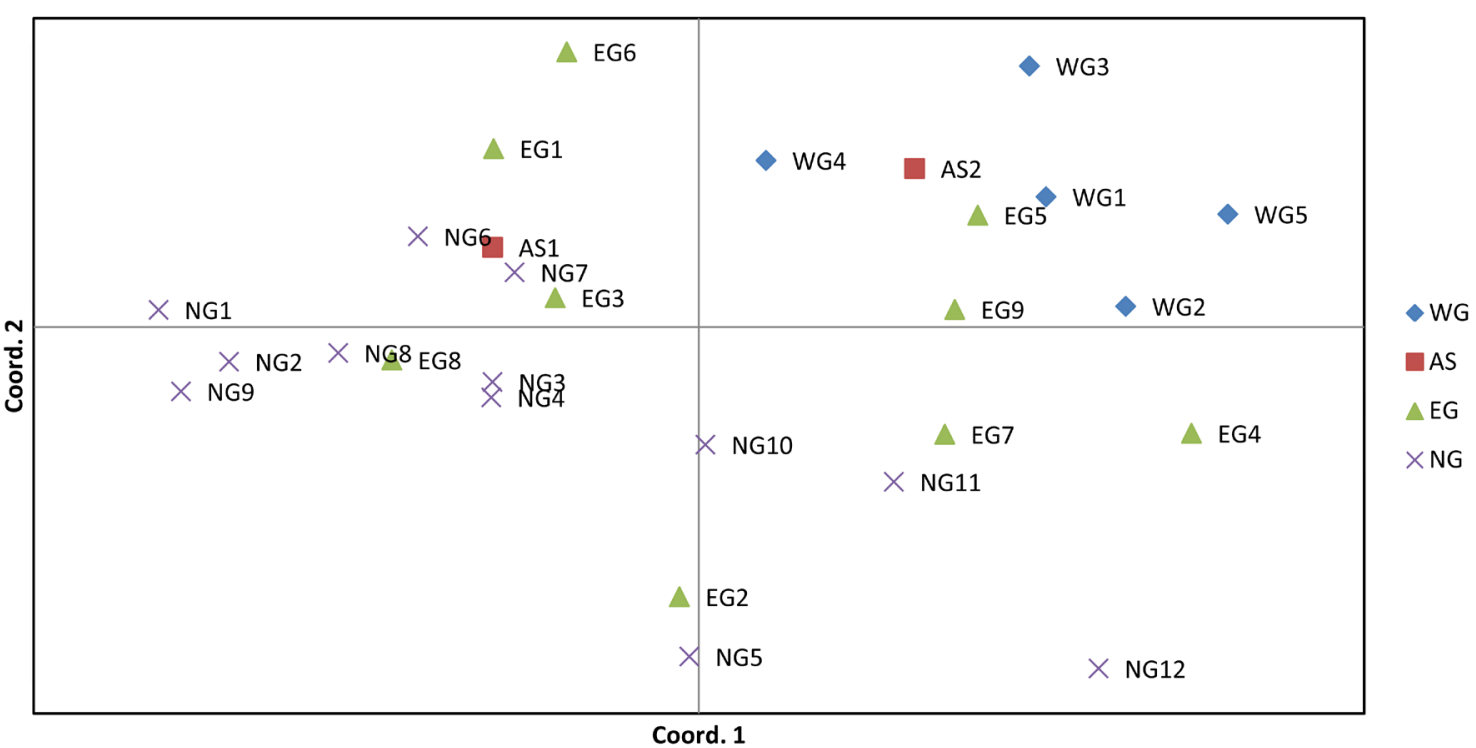

Figure 6 - Principal coordinate analysis plots of individuals based on the standardized covariance of genetic distance matrix. Different shapes and colors represent different geographic regions in Thailand. Axis coordinates 1 and 2 account for $17.901 \%$ and $12.988 \%$ of the total variance, respectively. 
value of Delta $\mathrm{K}$ can best show the real number of groups, based on the second order rate of change with respect to $\mathrm{K}$ of the likelihood function (Evanno et al., 2005). However, the graphical output by Distruct indicated that all sampled individuals exhibited admixture in the possible genetic clusters, with $\mathrm{K}$ ranging 2 to 5 (Figure 8). Even at $\mathrm{K}=2$, a weak genetic structure for the two inferred genetic clusters remained apparent. Cluster I was predominant in three locations (WG, AS, and $\mathrm{EG}$ ), with assignment probabilities were $74.5 \%, 66.9 \%$, and $57.9 \%$, respectively. Cluster II was predominant in NG,
(A)

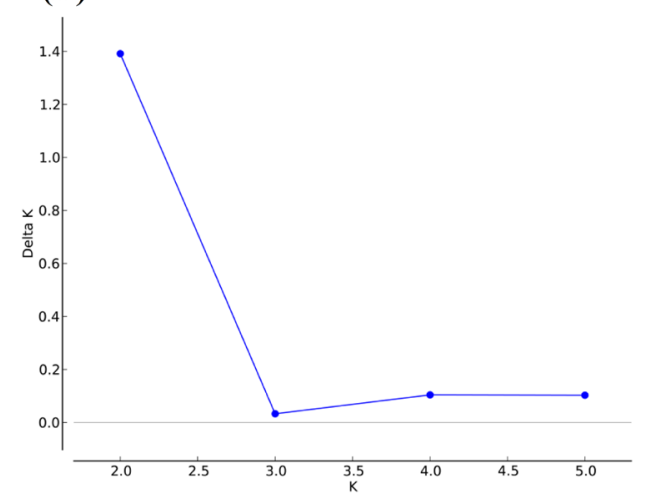

(C)

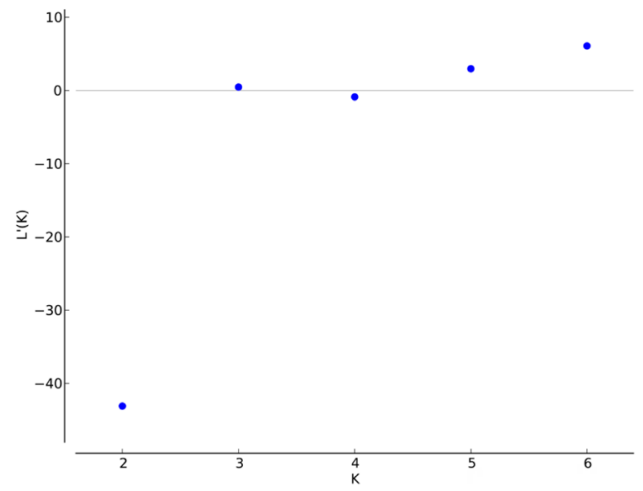

(B)

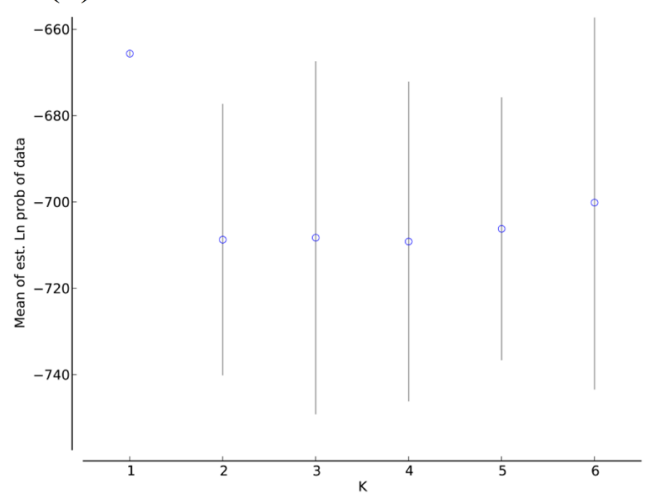

(D)

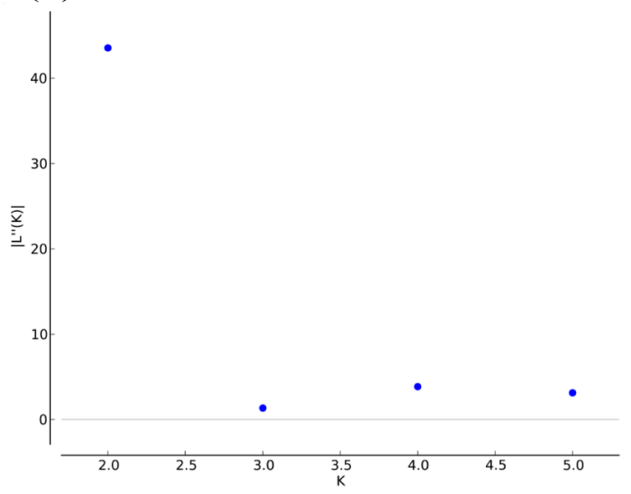

Figure 7 - Optimal K value determined by Structure Harvester online program. (A) Delta K; (B) L (K) (mean \pm SD); (C) Rate of change of the likelihood distribution; and (D) Absolute value of the 2nd order rate of change of the likelihood distribution.

(A)
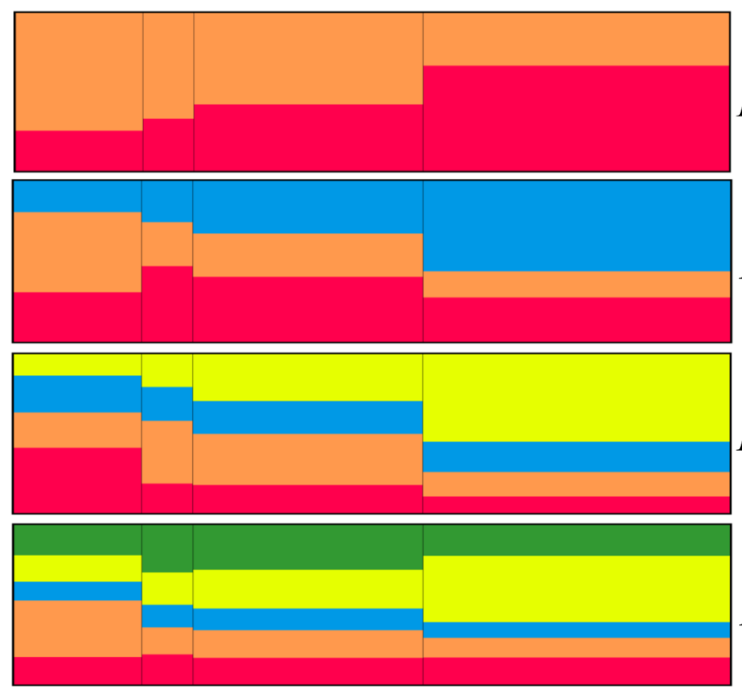

WG AS EG
(B)
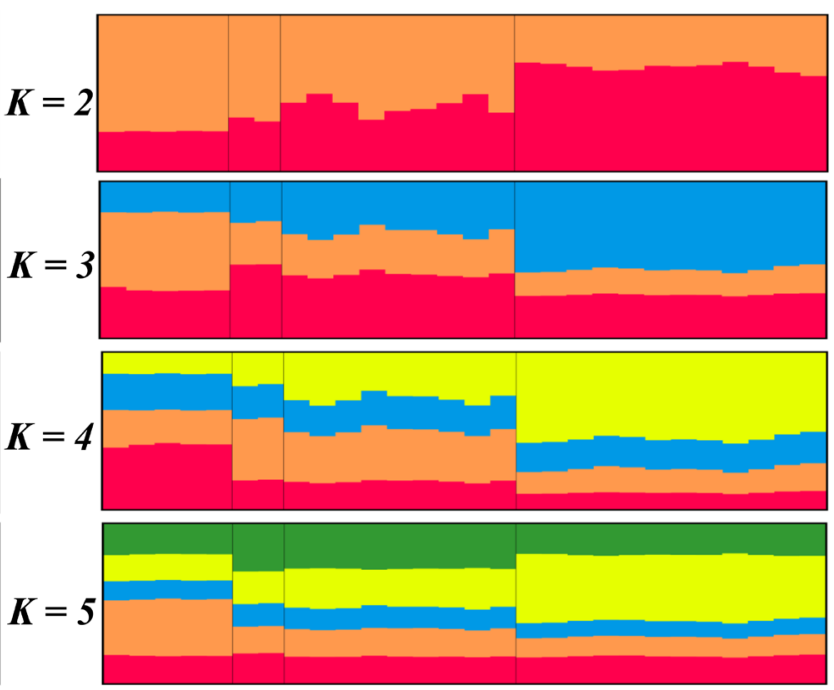

WG AS EG

NG

Figure 8 - Results of clustering (K varied from 2 to 5) calculated by Structure program based on (A) the population Q-matrix, and (B) the individual Q-matrix. Black vertical lines separate the four geographic regions in Thailand, and different colors represent the possible genetic clusters. 
with an assignment probability of $66.7 \%$. We also tried to identify possible partitions within cluster I and cluster II, but none was apparent.

Mantel tests revealed a positive and weak correlation $\left(r^{2}=0.0699, P=0.004\right)$ between the individual-by-individual genetic distances and geographic distances, indicating a pattern of IBD among the four geographic regions (Figure 9A). The result remained positive and significant when geographic coordinates and microsatellite data for two AS individuals were removed $\left(r^{2}=0.0665, P=0.001\right.$; Figure 9B).
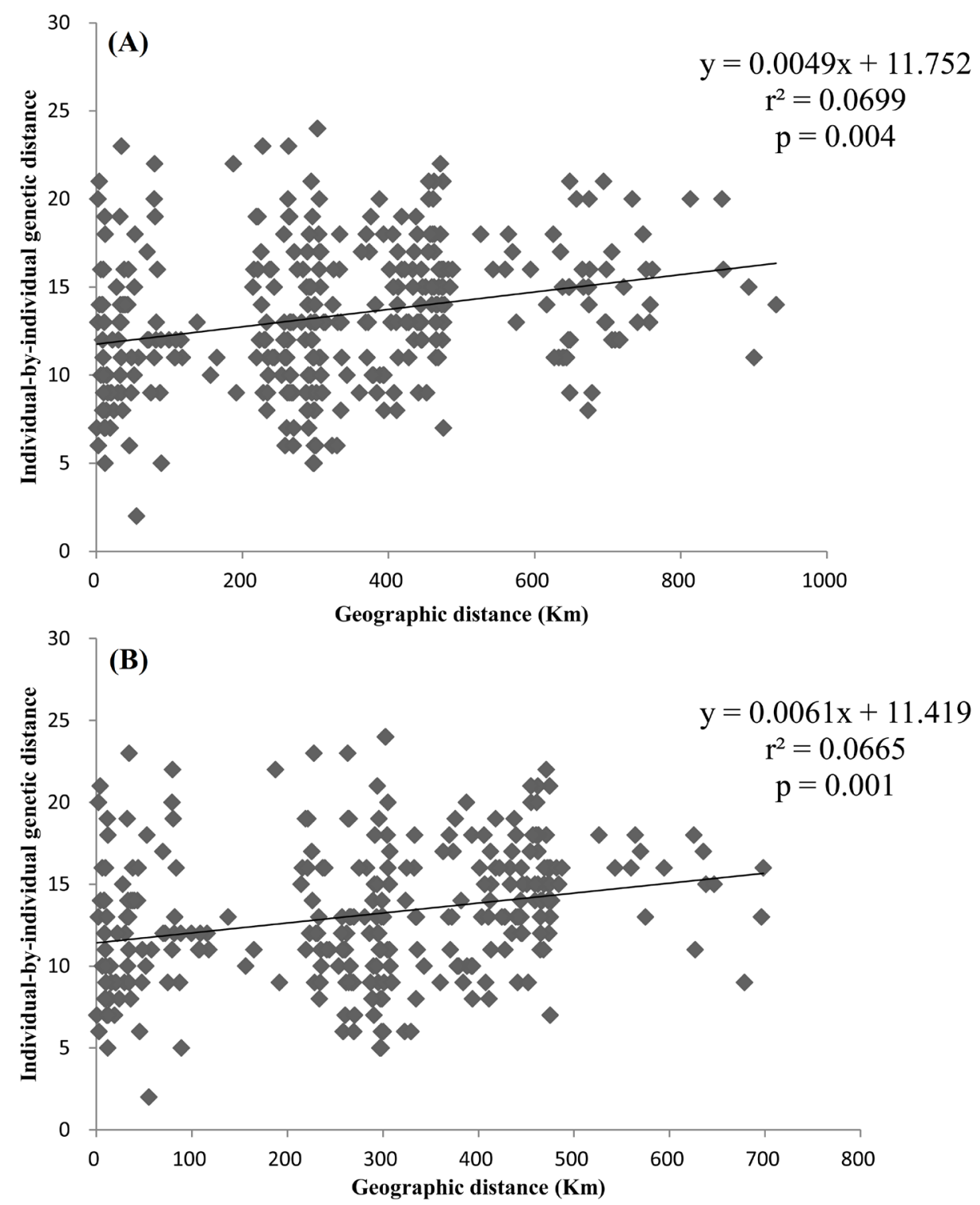

Figure 9 - Isolation by distance plots using individual-by-individual genetic distances and geographic distances (km) among (A) the four (WG, AS, EG, and NG), and (B) the three (WG, EG, and NG) sampling sites in Thailand. Geographic and microsatellite data of 27 individuals were included in analysis because of the missing location coordinates of one individual in Phetchaburi (NG).

\section{Discussion}

Some molecular markers with highly conserved primers have strong versatility during PCR. They can be invariant within species and sometimes even across broad taxonomic groups (Selkoe and Toonen, 2006). Microsatellites with highly conserved primer regions may be transferred from closely related species, but they rarely work across broad taxonomic groups (Glenn and Schable, 2005). Ten loci cross-amplified from other cetaceans (including Tursiops aduncus, T. truncatus, and $O$. orca) proved polymorphic in Mekong River O. brevirostris (Krützen et al., 2018). We report 10 of 18 tested loci isolated from $S$. chinensis to be polymorphic among $O$. brevirostris individuals from the four geographic locations in Thailand. These polymorphic markers will be useful for future molecular genetics studies on $O$. brevirostris and related species.

Based on microsatellite data, levels of genetic diversity we detected for $O$. brevirostris in Thailand waters (combined $\mathrm{Na}=5.90, \mathrm{Ne}=2.87, \mathrm{uHe}=0.59$, and $\mathrm{Ho}=0.51)$ are higher than those from Mekong River (combined $\mathrm{Na}=3.40, \mathrm{Ne}=$ $1.91, \mathrm{uHe}=0.45$, and $\mathrm{Ho}=0.41$ ) reported by Krützen et al. (2018). Differences in genetic diversity among $O$. brevirostris 
populations may be associated with the different polymorphic microsatellite markers used in these two studies. However, our analysis of mtDNA data also reveals that the haplotype and nucleotide diversities of $O$. brevirostris in Thailand (Hd $=0.925, \pi=0.900 \%)$ are much higher than those in Mekong River ( $\mathrm{Hd}=0.418, \pi=0.120 \%)$ and Chilika Lagoon (Hd $=0.345, \pi=0.078 \%$ ) reported by Caballero et al. (2019). Even if we remove the two individuals from AS, the genetic diversity of $O$. brevirostris within the Gulf of Thailand remains high ( $\mathrm{Hd}=0.915$ and $\pi=0.860 \%$ ), which is comparable to those in the Gulf of Thailand ( $\mathrm{Hd}=0.845$ and $\pi=1.150 \%$ ) reported by Caballero et al. (2019). A similar situation is reported for the similarly small Indo-Pacific finless porpoise Neophocaena phocaenoides, for which the genetic diversity of a riverine population was lower than coastal populations (Jia et al., 2014). It is likely that decreased genetic diversity in $O$. brevirostris in Mekong River and Chilika Lagoon is related to a small effective population size and long-term isolation.

ANOVA based on microsatellite data reveals significantly different $\mathrm{Na}$ values among the four sampling sites in Thailand, with the mean $\mathrm{Na}$ in $\mathrm{AS}$ the lowest. However, Ne values from these locations did not significantly differ. Ne is an estimate of the number of equally frequent alleles in an ideal population, which enables meaningful comparisons of allele diversity across loci with diverse allele frequency distributions (Peakall and Smouse, 2012, Appendix 1). There is also no significant difference in other genetic diversity estimators, such as mean values for $\mathrm{He}, \mathrm{uHe}$, Ho and I values. Compared with He and $\mathrm{uHe}$, the I value may be a better measure of allelic and genetic diversity, because it is not bounded by 1 (Peakall and Smouse, 2012, Appendix 1). Additionally, analysis of mtDNA data reveals $\mathrm{Hd}$ and $\pi$ values in AS are much higher than those in the other three regions. Results of genetic diversity indices in AS may be controversial because we could include only two individuals in genetic analysis. No significant differences were found in genetic diversity among WG, EG, and NG in the Gulf of Thailand.

Overall, genetic differentiation among geographic regions was statistically significant based on mtDNA and microsatellite analyses. Our results are consistent with statistical differences in average stable isotope values reported from $O$. brevirostris teeth in the same regions by JacksonRicketts et al. (2018), indicating distinct geographic groups (Eastern Gulf, Northern Gulf, Western Gulf, and Andaman Sea) may exist in Thailand's waters. However, no significant difference was detected for average tooth stable isotope values between northern and western Gulf regions. We report, to the contrary, significant genetic differences between NG and WG, suggesting $O$. brevirostris in these two regions are unlikely to be components of one large subpopulation, as stable isotope analysis is able to detect ecological populations, which may not correspond to genetic populations. Therefore, a lack of observed isotope differences might be due to similarities in habitat biochemistry in these two regions.

Our microsatellite data reveals the genetic structure of O. brevirostris in Thailand follows an IBD model, suggesting individual movements and exchanges are more likely to occur between adjacent regions. Therefore, the significant genetic differentiation detected between $\mathrm{WG}$ and $\mathrm{NG}$ regions might be explained by geographic distance (the mean distance between WG and NG individuals is $494.481 \mathrm{~km}$ ), which is larger than individual dispersal distances. Although smaller geographic distances (mean $228.072 \mathrm{~km}$ ) between EG and NG, significant genetic differentiation (both mtDNA and microsatellite data) remained between them. No significant genetic differentiation was found between AS and other regions based on different types of molecular markers, despite considerable distances between them (mean $653.853 \mathrm{~km}$ ) and obvious environmental breaks, such as the Strait of Malacca. Perhaps this is an artefact of small sample sizes in AS, and that more genetic data are needed to accurately determine population structure between this region and elsewhere.

Environmental factors and coastal development have likely played important roles in driving genetic differentiation of $O$. brevirostris in Thailand. Geographical barriers formed from oceanographic variables, such as ocean currents, upwelling, bathymetry, sea surface temperature, primary productivity, and salinity, can affect cetacean genetic structure (Bilgmann et al., 2007; Mendez et al., 2010; 2011; Amaral et al., 2012; 2017). In Thailand, O. brevirostris have been reported from along the coast of Trat province and the Bang Pakong Estuary adjacent to the Chonburi province (Tongnunui et al., 2011; Hines et al., 2015; Jackson-Ricketts et al., 2020). However, $O$. brevirostris today appears to be absent from approximately $250 \mathrm{~km}$ of coastline neighboring Chanthaburi and Rayong provinces, between Chonburi and Trat provinces. Shallow depths, high water turbidity, and short distances to river mouths may be linked to the distribution of $O$. brevirostris in the northern and eastern Gulf of Thailand (Tongnunui et al., 2011; Jackson-Ricketts et al., 2020). Anthropogenic barriers to individual dispersal caused by coastal development may also contribute to population fragmentation of inshore dolphins (Brown et al., 2014). Given anecdotal historical evidence for O. brevirostris occurring in Chanthaburi, its absence today may be also be related to higher levels of fishing pressure and industrial development in Chanthaburi and Rayong provinces (Jackson-Ricketts et al., 2020).

In addition to geographic distribution patterns, and environmental and anthropogenic factors, adaptations caused by the complex social behaviors of cetaceans may contribute to genetic divergence (Mendez et al., 2013; Fruet et al., 2014). Some social and specialized foraging behaviors have been reported to be associated with significant levels of population structure in T. aduncus (Krützen et al., 2004; Frère et al., 2010) and O. orca (Ford et al., 1998; Matkin et al., 2007; Riesch et al., 2012). We speculate that local adaptations related to foraging strategies may have contributed to genetic differentiation of $O$. brevirostris in Thailand, because isotopic dietary analysis reveals $O$. brevirostris forages on different proportions of prey in neighboring locations where geographic barriers in the eastern Gulf of Thailand are lacking (JacksonRicketts et al., 2018). Therefore, O. brevirostris in Thailand may have high site fidelity because of local prey resources and specialized foraging behavior.

\section{Conclusion}

In this study, 10 microsatellites were successfully cross-amplified and demonstrated to be polymorphic in $O$. 
brevirostris from the eastern, western, and northern Gulf of Thailand and Andaman Sea coast. Based on analyses of both mtDNA and microsatellites, genetic diversity does not differ significantly among sampling locations in the Gulf of Thailand, but significant genetic differentiation is apparent between different region pairs. We speculate that significant genetic structure is associated with a combination of geographical distribution patterns, environmental and anthropogenic factors, and local behavioral adaptations.

Caution interpreting these results should be exercised because our sample size for each region was small, and samples were collected in an opportunistic manner, in that all individuals were dead (beach stranded). Our results, together with isotope variability in teeth (Jackson-Ricketts et al., 2018), indicate that $O$. brevirostris may use specific habitats and have restricted home ranges throughout the life cycle in Thailand's waters. An improved understanding of the level of conservation and management for $O$. brevirostris in Thailand's waters will require more attention being paid to demographic, ecological and genetic-related issues regarding this endangered species.

\section{Acknowledgments}

This work was financially supported by the National Natural Science Foundation for Young Scholars of China (Grant No. 41806135), the Scientific Research Foundation of Third Institute of Oceanography, Ministry of Natural Resources (Grant No. 2020017 and 2018015), the Natural Science Foundation for Young Scholars of Fujian Province (Grant No. 2016J05078), and the China-ASEAN Marinetime Cooperation Fund (Grant No. HX150702 and HX01-190701). We thank Steve O'Shea, PhD, from Liwen Bianji, Edanz Editing China (https://www.liwenbianji.cn/ac), for editing the English text of a draft of this manuscript. Finally, we express our sincere thanks to editors and the anonymous reviewer for their invaluable comments that significantly improved our manuscript.

\section{Conflict of interest}

The authors declare no conflicts of interest.

\section{Author Contributions}

$\mathrm{YD}, \mathrm{KK}$, and XW conceived the study; YD and RC conducted the experiments, analyzed the data and wrote the manuscript; WS contributed to sample collection and DNA extraction; LZ, RA and FW contributed to data analysis and revising the manuscript; $\mathrm{KK}$ and $\mathrm{XW}$ supervised the whole project; all authors read and approved the final version.

\section{References}

Amaral AR, Beheregaray LB, Bilgmann K, Boutov D, de Freitas LA, Robertson KM, Sequeira M, Stockin KA, Coelho MM and Moeller LM (2012) Seascape genetics of a globally distributed, highly mobile marine mammal: The short-beaked common dolphin (Genus Delphinus). PLoS One 7:e31482.

Amaral AR, Smith BD, Mansur RM, Brownell RL and Rosenbaum HC (2017) Oceanographic drivers of population differentiation in Indo-Pacific bottlenose (Tursiops aduncus) and humpback (Sousa spp.) dolphins of the northern Bay of Bengal. Conserv Genet 18:371-381.
Anderson M and Kinze CC (1999) Annotated checklist and identification key to the whales, dolphins, and porpoises (Order Cetacea) of Thailand and adjacent waters. Nat Hist Bull Siam Soc 47:27-62.

Barbara T, Palma-Silva C, Paggi GM, Bered F, Fay MF and Lexer C (2007) Cross-species transfer of nuclear microsatellite markers: Potential and limitations. Mol Ecol 16:3759-3767.

Beasley IL, Chooruk S and Piwpong N (2002) The status of the Irrawaddy dolphin, Orcaella brevirostris, in Songkhla Lake, Southern Thailand. Raffles Bull Zool 10:75-83.

Beasley IL, Pollock K, Jefferson TA, Arnold P, Morse L, Yim S, Lor Kim S and Marsh H (2013) Likely future extirpation of another Asian river dolphin: The critically endangered population of the Irrawaddy dolphin in the Mekong River is small and declining. Mar Mamm Sci 29:226-252.

Bilgmann K, Moller LM, Harcourt RG, Gibbs SE and Beheregaray LB (2007) Genetic differentiation in bottlenose dolphins from South Australia: Association with local oceanography and coastal geography. Mar Ecol Prog Ser 341:265-276.

Bonin A, Bellemain E, Bronken Eidesen P, Pompanon F, Brochmann $\mathrm{C}$ and Taberlet $\mathrm{P}$ (2004) How to track and assess genotyping errors in population genetics studies. Mol Ecol 13:3261-3273.

Brown AM, Kopps AM, Allen SJ, Bejder L, Littleford-Colquhoun B, Parra GJ, Cagnazzi D, Thiele D, Palmer C et al. (2014) Population differentiation and hybridisation of Australian Snubfin (Orcaella heinsohni) and Indo-Pacific Humpback (Sousa chinensis) Dolphins in North-Western Australia. PLoS One:e101427.

Caballero S, Dove V, Jackson-Ricketts J, Junchompoo C, Cohen S and Hines E (2019) Mitochondrial DNA diversity and population structure in the Irrawaddy dolphin (Orcaella brevirostris) from the Gulf of Thailand and the Mekong River. Mar Mamm Sci 35:300-310.

Carvajal-Rodriguez A (2018) Myriads: P-value-based multiple testing correction. Bioinformatics 34:1043-104.

Chantrapornsyl S, Adulyanukosol K and Kittiwathanawong K (1996) Records of cetaceans in Thailand. Res Bull 61:39-63.

Chantrapornsyl S, Adulyanukosol K and Kittiwattanawong K (1999) Stranded cetaceans from Thailand. IBI Reports 9:55-72.

Cornuet JM and Luikart G (1996) Description and power analysis of two tests for detecting recent population bottlenecks from allele frequency data. Genetics 144:2001-2014.

De Barba M, Miquel C, Lobréaux S, Quenette PY, Swenson JE and Taberlet P (2017) High-throughput microsatellite genotyping in ecology: Improved accuracy, efficiency, standardization and success with low-quantity and degraded DNA. Mol Ecol Resour 17:492-507.

Dolar MLL, Perrin WF, Gaudiano JP, Yaptinchay AASP and Tan JML (2002) Preliminary report on a small estuarine population of Irrawaddy dolphins Orcaella brevirostris in the Philippines. Raffles Bull Zool 10:155-160.

Earl DA and VonHoldt BM (2012) Structure Harvester: A website and program for visualizing Structure output and implementing the Evanno method. Conserv Genet Resour 4:359-361.

Evanno G, Regnaut S and Goudet J (2005) Detecting the number of clusters of individuals using the software STRUCTURE: A simulation study. Mol Ecol 14:2611-2620.

Excoffier L, Laval G and Schneider S (2005) Arlequin (version 3.0): An integrated software package for population genetics data analysis. Evol Bioinform 1:47-50.

Ford JK, Ellis GM, Barrettlennard LG, Morton AB, Palm RS and Balcomb KC (1998) Dietary specialization in two sympatric populations of killer whales (Orcinus orca) in coastal British Columbia and adjacent waters. Can J Zool 76:1456-1471. 
Frère CH, Krützen M, Mann J, Watson-Capps JJ, Tsai YJ, Patterson EM, Connor R, Bejder L and Sherwin WB (2010) Home range overlap, matrilineal and biparental kinship drive female associations in bottlenose dolphins. Anim Behav 80:481-486.

Fruet PF, Secchi ER, Daura-Jorge F, Vermeulen E, Flores P, SimoesLopes P, Genoves R, Laporta P, DiTullio J and Möller L (2014) Remarkably low genetic diversity and strong population structure in common bottlenose dolphins (Tursiops truncatus) from coastal waters of the Southwestern Atlantic Ocean. Conserv Genet 15:879-895.

Glenn TC and Schable NA (2005) Isolating microsatellite DNA loci. Methods Enzymol 395:202-222.

Goudet J (1995) FSTAT (version 1.2): A computer program to calculate F-statistics. J Hered 86:485-486.

Hines EM, Samantha S, Chalatip J, Ponnampalam LS, Ilangakoon AD, Jackson-Ricketts J and Monanunsap S. (2015) Line transect estimates of Irrawaddy dolphin abundance along the eastern Gulf Coast of Thailand. Front Mar Sci 2:63.

Hoelzel AR, Hancock JM and Dover GA (1991) Evolution of the cetacean mitochondrial D-loop region. Mol Biol Evol 8:475-493.

Hubisz MJ, Falush D, Stephens M and Pritchard JK (2009) Inferring weak population structure with the assistance of sample group information. Mol Ecol Resour 9:1322-1332.

Hurst GD and Jiggins FM (2005) Problems with mitochondrial DNA as a marker in population, phylogeographic and phylogenetic studies: The effects of inherited symbionts. Proc R Soc Lond B Biol Sci 272:1525-1534.

Jackson-Ricketts J, Ruiz-Cooley RI, Junchompoo C, Thongsukdee S and Costa DP (2018) Ontogenetic variation in diet and habitat of Irrawaddy dolphins (Orcaella brevirostris) in the Gulf of Thailand and the Andaman sea. Mar Mamm Sci 35:492-521.

Jackson-Ricketts J, Junchompoo C, Hines E, Hazen EL, Ponnampalam LS, Ilangakoon AD and Monanunsap S (2020) Habitat modeling of Irrawaddy dolphins (Orcaella brevirostris) in the Eastern Gulf of Thailand. Ecol Evol 10:2778-2792.

Jakobsson M and Rosenberg NA (2007) CLUMPP: A cluster matching and permutation program for dealing with label switching and multimodality in analysis of population structure. Bioinformatics 23:1801-1806.

Jayasankar P, Patel A, Khan MZ, Das P and Panda S (2011) Mitochondrial DNA diversity and PCR-based sex determination of Irrawaddy dolphin (Orcaella brevirostris) from Chilika Lagoon, India. Mol Biol Rep 38:1661-1668.

Jefferson TA, Hung SK and Würsig B (2009) Protecting small cetaceans from coastal development: Impact assessment and mitigation experience in Hong Kong. Mar Policy 33:305-311.

Jia K, Lin W, Gui D, Karczmarski L and Wu Y (2014) Molecular evidence reveals the distinctiveness of Indo-Pacific finless porpoises (Neophocaena phocaenoides) in the Pearl River Estuary and insights into genus Neophocaena's origin. Mar Biol 161:1919-1930.

Jutapruet S, Intongcome A, Wang X, Kittiwattanawong K and Huang S (2017) Distribution of three sympatric cetacean species off the coast of the Central-Western Gulf of Thailand. Aquat Mamm 43:465-473.

Kittiwattanawong K, Chantrapornsyl S, Ninwat S and Chooruk S (2007) Review of the status and conservation of Irrawaddy dolphins Orcaella brevirostris in the Songkhla Lake of Thailand. In: Smith BD, Shore RG and Lopez A. Status and conservation of freshwater populations of Irrawaddy dolphins (Working paper 31). Wildlife Conservation Society, New York, pp 83-86.

Kreb D (2004) Abundance of freshwater Irrawaddy dolphins in the Mahakam River in East Kalimantan, Indonesia, based on mark-recapture analysis of photo-identified individuals. J Cetacean Res Manag 6:269-277.

Krützen M, Sherwin WB, Berggren P and Gales NJ (2004) Population structure in an inshore cetacean revealed by microsatellite and mtDNA analysis: Bottlenose dolphins (Tursiops sp.) in Shark Bay, Western Australia. Mar Mamm Sci 20:28-47.

Krützen M, Isabel B, Ackermann CY, Dietmar L, Arne L, Ryan GE, Bejder L, Parra GJ, Wolfensberger R and Spencer PBS (2018) Demographic collapse and low genetic diversity of the Irrawaddy dolphin population inhabiting the mekong river. PLoS One 13:e189200.

Kundu S, Sharma G, Balakrishnan S, Tyagi K, Chandra K and Kumar V (2019) DNA barcoding identified two endangered dolphins: Threats on living aquatic mammals in India. Mitochondrial DNA B Resour 4:77-80.

Leigh JW and Bryant D (2015) Popart: Full-feature software for haplotype network construction. Methods Ecol Evol 6:1110 1116.

Librado P and Rozas J (2009) DnaSP v5: A software for comprehensive analysis of DNA polymorphism data. Bioinformatics 25:14511452.

Mace GM and Lande R (1991) Assessing extinction threats: Toward a reevaluation of IUCN Threatened Species categories. Conserv Biol 5:148-157.

Mantel N (1967) The detection of disease clustering and a generalized regression approach. Can Res 27:209-220.

Matkin CO, Barrett-Lennard LG, Yurk H, Ellifrit D and Trites AW (2007) Ecotypic variation and predatory behavior among killer whales (Orcinus orca) off the eastern Aleutian Islands, Alaska. Fish Bull 105:74-87.

Mendez M, Rosenbaum HC, Subramaniam A, Yackulic C and Bordino $P$ (2010) Isolation by environmental distance in mobile marine species: Molecular ecology of franciscana dolphins at their southern range. Mol Ecol 19:2212-2228.

Mendez M, Subramaniam A, Collins T, Minton G, Baldwin R, Berggren P, Sarnblad A, Amir OA, Peddemors V, Karczmarski L et al. (2011) Molecular ecology meets remote sensing: Environmental drivers to population structure of humpback dolphins in the Western Indian Ocean. Heredity 107:349-361.

Mendez M, Jefferson TA, Kolokotronis S-O, Krützen M, Parra GJ, Collins T, Minton G, Baldwin R, Berggren P, Särnblad A et al. (2013) Integrating multiple lines of evidence to better understand the evolutionary divergence of humpback dolphins along their entire distribution range: A new dolphin species in Australian waters? Mol Ecol 22:5936-5948.

Minton G, Peter C and Tuen AA (2011) Distribution of small cetaceans in the nearshore waters of Sarawak, East Malaysia. Raffles Bull Zool 59:91-100.

Minton G, Peter C, Zulkifli Poh AN, Ngeian J, Braulik G, Hammond PS and Tuen AA. (2013) Population estimates and distribution patterns of Irrawaddy dolphins (Orcaella brevirostris) and Indo-Pacific finless porpoise (Neophocaena phocaenoides) in the Kuching Bay, Sarawak. Raffles Bull Zool 61:877-888.

Minton G, Smith BD, Braulik GT, Kreb D, Sutaria D and Reeves R (2017) Orcaella brevirostris (errata version published in 2018), The IUCN Red List of Threatened Species, https:// www.iucnredlist.org/species/15419/123790805

Niu FQ, Yang YM, Zhou ZM, Wang XY, Monanunsap S and Junchompoo C (2019) Echolocation clicks of free-ranging Irrawaddy dolphins (Orcaella brevirostris) in Trat Bay, the eastern Gulf of Thailand. J Acoust Soc Am 145:3031-3037.

Peakall R, Smouse PE and Huff DR (1995) Evolutionary implications of allozyme and RAPD variation in diploid populations of dioecious buffalograss Buchloë dactyloides. Mol Ecol $4: 135-148$. 
Peakall R and Smouse PE (2006) GenAlEx 6: Genetic analysis in Excel. Population genetic software for teaching and research. Mol Ecol Notes 6:288-295.

Peakall R and Smouse PE (2012) GenAlEx 6.5: Genetic analysis in Excel. Population genetic software for teaching and research - an update. Bioinformatics 28:2537-2539.

Piry S, Luikart G and Cornuet JM (1999) BOTTLENECK: A computer program for detecting recent reductions in the effective population size using allele frequency data. J Hered 90:502-503.

Pompanon F, Bonin A, Bellemain E and Taberlet P (2005) Genotyping errors: Causes, consequences and solutions. Nat Rev Genet 6:847-859.

Pritchard JK, Stephens M and Donnelly P (2000) Inference of population structure using multilocus genotype data. Genetics 155:945-959.

Riesch R, Barrettlennard LG, Ellis GM, Ford JK and Deecke VB (2012) Cultural traditions and the evolution of reproductive isolation: Ecological speciation in killer whales? Biol J Linn Soc Lond 106:1-17.

Rosenberg NA (2004) DISTRUCT: A program for the graphical display of population structure. Mol Ecol Notes 4:137-138.

Rousset F (2008) GENEPOP' 007: A complete re-implementation of the GENEPOP software for Windows and Linux. Mol Ecol Resour 8:103-106.

Selkoe KA and Toonen RJ (2006) Microsatellites for ecologists: A practical guide to using and evaluating microsatellite markers. Ecol Lett 9:615-629.

Shen Z, Qu W, Wang W, Lu Y, Wu Y, Li Z, Hang X, Wang X, Zhao D and Zhang C. (2010) MPprimer: A program for reliable multiplex PCR primer design. BMC Bioinformatics 11:143.

Smith BD and Hobbs L (2002) Status of Irrawaddy dolphins Orcaella brevirostris in the upper reaches of the Ayeyarwady River, Myanmar. Raffles Bull Zool 10:67-73.

Smith BD, Beasley I and Kreb D (2003) Marked declines in populations of Irrawaddy dolphins. Oryx 37:401-406.

Smith BD, Braulik GT, Strindberg S, Ahmed B and Mansur RM (2006) Abundance of Irrawaddy dolphins (Orcaella brevirostris) and Ganges River dolphins (Platanista gangetica gangetica) estimated using concurrent counts made by independence teams in waterways of the Sundarbans mangrove forest in Bangladesh. Mar Mamm Sci 22:527-547.

Smouse PE and Peakall R (1999) Spatial autocorrelation analysis of individual multiallele and multilocus genetic structure. Heredity 82:561-573.

Stacey PJ and Arnold PW (1999) Orcaella brevirostris. Mammalian Species 616:1-8.
Sutaria D and Marsh H (2011) Abundance estimates of Irrawaddy dolphins in Chilka Lagoon, India, using photo-identification based mark-recapture methods. Mar Mamm Sci 27:338-348.

Taberlet P, Griffin S, Goossens B, Questiau S, Manceau V, Escaravage N, Bouvet, J (1996) Reliable genotyping of samples with very low DNA quantities using PCR. Nucleic Acids Res 24:3189-3194.

Tamura K, Peterson DS, Peterson N, Stecher G, Nei M and Kumar S (2011) MEGA5: Molecular evolutionary genetics analysis using maximum likelihood, evolutionary distance, and maximum parsimony methods. Mol Biol Evol 28:2731-2739.

Tongnunui S, Wattanakornsiri A, Pachana K, Beamish FW and Tongsukdee S (2011) Preliminary investigation of Irrawaddy dolphin (Orcaella brevirostris) in the Bangpakong Estuary, Inner Gulf of Thailand. Environ Nat Resour J 9:48-57.

Van Oosterhout C, Hutchinson WF, Wills DPM and Shipley P (2004) Micro-checker: Software for identifying and correcting genotyping errors in microsatellite data. Mol Ecol Notes 4:535-538.

Weir BS and Cockerham CC (1984) Estimating F-statistics for the analysis of population structure. Evolution 38:1358-1370.

Wilcoxon F (1945) Individual comparisons by ranking methods. Biometrics Bull 1:80-83.

Wilson AC, Cann RL, Carr SM, George MR, Gyllensten UB, HelmBychowski KM, Higuchi R, Palumbi S, Prager E, Sage R and Stoneking M (1985) Mitochondrial DNA and two perspectives on evolutionary genetics. Biol J Linn Soc Lond 26:375-400.

\section{Supplementary Material}

The following online material is available for this article:

Table S1 - Multiplex design information for all the tested 18 microsatellite loci for $O$. brevirostris in Thailand.

Table S2 - GenBank accession number of all the $32 \mathrm{mtDNA}$ sequences including 15 haplotypes for $O$. brevirostris in Thailand.

Table S3 - Genetic diversity parameters in four sampling locations of $O$. brevirostris in Thailand.

Associate Editor: Antonio Matteo Solé-Cava

License information: This is an open-access article distributed under the terms of the Creative Commons Attribution License (type CC-BY), which permits unrestricted use, distribution and reproduction in any medium, provided the original article is properly cited. 